\title{
Vegetation and environments since the Last Glacial Maximum in the Southern Tablelands, New South Wales
}

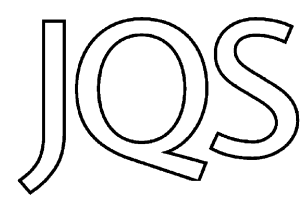

\author{
JUSTINE KEMP*,+ and GEOFF HOPE \\ Department of Archaeology and Natural History, ANU College of Asia and the Pacific, The Australian National University, \\ Canberra, 0200, Australia
}

Received 3 August 2014; Revised 17 September 2014; Accepted 27 September 2014

\begin{abstract}
Regional changes in vegetation and environment in the last 16 ka have been reconstructed from Micalong Swamp and Willigobung Swamp $\left(35^{\circ} \mathrm{S}\right)$ on the western Southern Tablelands of New South Wales (NSW). Micalong Swamp lies at $980 \mathrm{~m}$ above sea level (a.s.I.), which is close to the subalpine treeline at this latitude. Willigobung Swamp (780 m a.s.l.) approaches the modern ecotone between dry and wet montane forest formations. The sites are sensitive to shifts in temperature and precipitation and are the first reported pollen records from the western montane slopes of NSW. A radiocarbon-based chronology indicates that Micalong Swamp was a swampy, gravel floodplain surrounded by alpine grassland before $16.1 \mathrm{ka}$. Subalpine woodland may have become established at $1000 \mathrm{~m}$ by 16-14 ka. Organic fen sedimentation developed $<11.8 \mathrm{ka}$ at Willigobung, and $\sim 11.7 \mathrm{ka}$ at the higher elevation Micalong Swamp. Wet forest elements were present at both sites around 10 ka and persisted for 3-4 ka. Sedimentation in a shallow lake or fen between 10 and 8 ka supports this evidence for wetter conditions in the early Holocene. In the late Holocene an expansion of subalpine flora between 2.7 and $0.9 \mathrm{ka}$ preceded by shallow lake/fen sedimentation is consistent with regional evidence for neoglacial cooling.

Copyright (C) 2014 John Wiley \& Sons, Ltd.
\end{abstract}

KEYWORDS: charcoal; fen peatlands; late Quaternary; pollen; south-eastern Australia; vegetation history.

\section{Introduction}

A comparison of late Quaternary climate change in the Northern and Southern Hemispheres is a subject of ongoing debate and major research efforts are presently underway to integrate regional records from the Southern Hemisphere to facilitate hemispheric and global analyses (e.g. Barrows et al., 2013). Even in some temperate regions of Australia this aim has been thwarted by a lack of data (Reeves et al., 2013). In south-eastern Australia, much of the continuous record of changing environments comes from pollen histories extracted from lakes, fens and peat bogs. Lake records are scarce below the alpine zone, and periodic drying and low organic contents have adversely affected pollen preservation and increased the dating uncertainties (e.g. Singh and Geissler, 1985). Alpine and montane peat bogs have better pollen preservation, but their small scale yields essentially local vegetation histories. In southern New South Wales (NSW), fen peatlands were widespread until the introduction of European-style agriculture, which resulted in the incision and erosion of organic valley fills, particularly in the middle and lower reaches of the river systems (Wasson et al., 1998). The preserved remnants of these fens remain sufficiently numerous to capture the regional pollen rain and are less susceptible to erosion, drying and fire. This paper reviews vegetation change in the NSW Southern Tablelands, and presents two new records from montane fens in the upper Murrumbidgee Basin. As the first pollen records reported from the western montane belt of the Southern Tablelands, they fill an important gap in our knowledge of late Quaternary environments in the region.

\section{Environmental setting}

The NSW Southern Tablelands $\left(35-37^{\circ} \mathrm{S}\right)$ is an $\sim 180-\mathrm{km}$-wide belt of mountain ranges and tablelands that separates the

${ }^{*}$ Correspondence: J. Kemp.

E-mail: j.kemp@griffith.edu.au

'Present address: Australian Rivers Institute, Griffith University, Nathan, Queensland, 4122, Australia. interior lowlands of the Murray Basin from the coastal plain (Fig. 1). Its eastern edge is defined by the Great Escarpment and coastal ranges over $1000 \mathrm{~m}$. On its western edge, stepped plateaux climb to $1500 \mathrm{~m}$ elevation with peaks rising over $2000 \mathrm{~m}$ along the Snowy Mountains. Cirque basins and glacial moraine are found on the highest peaks and cosmogenic dating of moraine has identified a series of glaciations between 60 and $17 \mathrm{ka}$ (Barrows et al., 2001). Relict periglacial landforms above $1000 \mathrm{~m}$ were active during the last glacial maximum (Galloway, 1965; Barrows et al., 2004). On the northern ranges of the Australian Alps the treeline lies at $1900 \mathrm{~m}$, which exceeds the highest peaks in the area, but the orographic treeline falls to $\sim 1300 \mathrm{~m}$ on exposed plateau surfaces (McDougall and Walsh, 2007). Subalpine vegetation prevails above $1500 \mathrm{~m}$ and is dominated by Eucalyptus pauciflora (snow gum) woodland with a grass or shrub understorey. In valley bottoms above $1000 \mathrm{~m}$ the treeline may be inverted owing to cold air drainage. Montane wet eucalypt forest occupies altitudes between 900 and $1500 \mathrm{~m}$ at this latitude (Costin, 1954). The regional climate is temperate with a distinctly warm and dry summer (Stern et al., 2000). In winter, the dominant source of moisture results from fronts embedded in the westerly winds, and regular, severe frosts play an important role in the mechanical weathering of soils above $1000 \mathrm{~m}$ (Costin, 1954).

\section{Micalong Swamp}

Micalong Swamp $\left(35.318^{\circ} \mathrm{S}, 148.524^{\circ} \mathrm{E}\right)$ is located on the north-west plateau of the Fiery Range (Fig. 1). The plateau is underlain by Silurian-Devonian dolerites intruded by younger granite. The fen sits at $980 \mathrm{~m}$ and extends downstream for $\sim 4 \mathrm{~km}$ within a 200-m-wide, fault-aligned valley near the headwaters of Micalong Creek. Surrounding hills rise to $1200 \mathrm{~m}$ elevation. The valley fill comprises $\sim 1 \mathrm{~km}^{2}$ of topogenous fen with an average depth of $4 \mathrm{~m}$, grading downstream to humic silty flats now being actively incised by the stream (Hope and Southern, 1983). Climate records available 


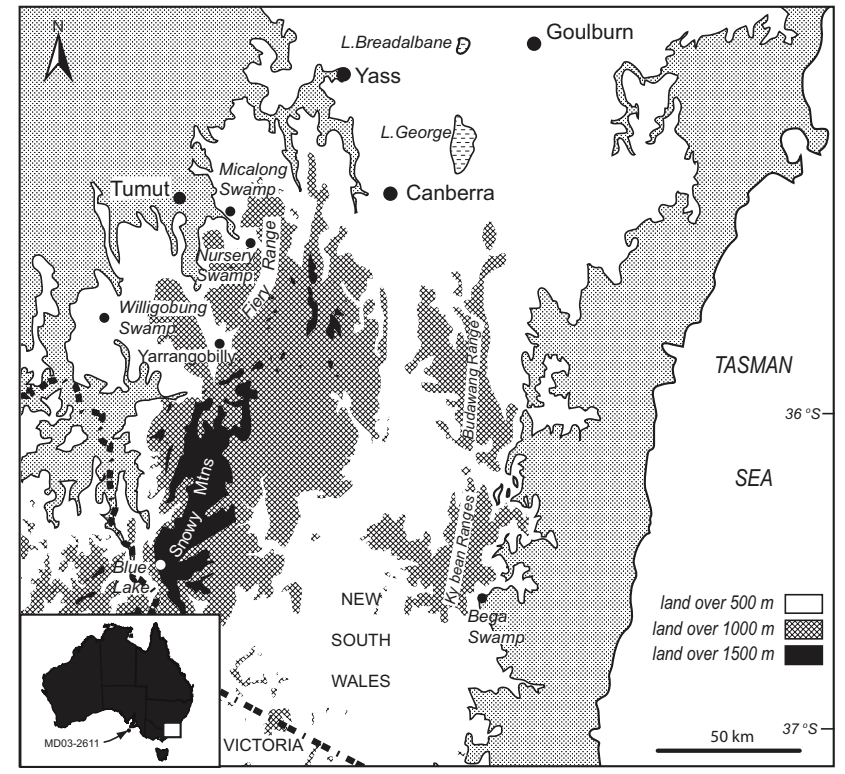

Figure 1. Map of the Southern Tablelands, NSW, showing the locations of places mentioned in the text.

from Bondo Forestry Station, $5 \mathrm{~km}$ westwards at $840 \mathrm{~m}$, indicate a mean January temperature of $18.2^{\circ} \mathrm{C}$ and mean winter temperature of $4.2{ }^{\circ} \mathrm{C}$. Average annual precipitation at Bondo is $1240 \mathrm{~mm}$ with a slight winter maximum, and precipitation decreases with altitude and distance westward to $816 \mathrm{~mm}$ at Tumut, $26 \mathrm{~km}$ westward at $300 \mathrm{~m}$ elevation (Bureau of Meteorology, 2013).

Hope and Southern (1983) surveyed the local vegetation at Micalong Swamp. The fen is dominated by Carex gaudichaudiana with a fringing montane Sphagnum bog that includes shrub species of Leptospermum, Epacris, Hakea and Baeckea (Hope et al., 2009). Other aquatic taxa represented in the fen include Poaceae, other graminoids in the Cyperaceae, Juncaceae, Orchidaceae and Restionaceae, fern species in Blechnum and
Adiantum, and herbs such as Epilobium, Apiaceae-Araliaceae, Myriophyllum, Ranunculus, Neopaxia and Stellaria. The fen margins have introduced weeds including blackberry (Rubus fruticosus), Centaurium, clovers (Trifolium and Medicago), Plantago and flatweeds such as Hypochoeris radicata.

Vegetation surrounding the fen is Eucalyptus stellulata-E. pauciflora - E. camphora woodland with a grassy understorey of Polystichum and Blechnum ferns and scattered small trees of Acacia melanoxylon, Lomatia and Polyscias. Large areas have been cleared for conifer plantation but remnant native vegetation above $900 \mathrm{~m}$ is tall open forest dominated by $E$. dalrympleana with an understorey characteristic of both wet and dry forests, including Tasmannia lanceolata, Dicksonia antarctica and Acacia dealbata, and shrub species of Fabaceae and Asteraceae: Daviesia, Platylobium, Helichrysum, Olearia and Cassinia. Below $900 \mathrm{~m}$, open forest of $E$. dives or $E$. radiata dominates with Callitris appearing at lower altitudes.

Evidence for Aboriginal occupation of Micalong Swamp comes from scattered flakes of quartz and chert around the banks and from nine known occupation sites in the catchment (Hiscock, 1983). Backed blades were also found by Flood (1980, p. 213), which suggests continuous occupation for at least $4 \mathrm{ka}$. The precise use the Aborigines made of the fen is unknown, although reliable water is likely to have been a precious resource in the Tablelands (Hiscock, 1983). Hume and Hovell encountered the 'mountain swamp' on their exploration of the region in 1824 (Bland, 1831). They sighted distant fires but no Aborigines in this open country with good grass, which had the appearance of being regularly burned. In the late 19th century, 'The Micalong' supported several pastoral families, and was the northern entrance of a much-used stock route into the high country. Gold was mined briefly at Chinaman's Creek (Fig. 2A). Summer grazing and regular burns were conducted until the $1950 \mathrm{~s}$. Nowadays, disturbance from these activities appears to be minimal except for the legacy of introduced weeds. In 1969, the slopes around the lower half of the fen were cleared to make way for Pinus plantation. The fen was gazetted as part of the Micalong Swamp Flora Reserve in 1985.
Figure 2. (A) Micalong Swamp, Fiery Ranges, NSW. (B) Willigobung Swamp near Tumbarumba, NSW.

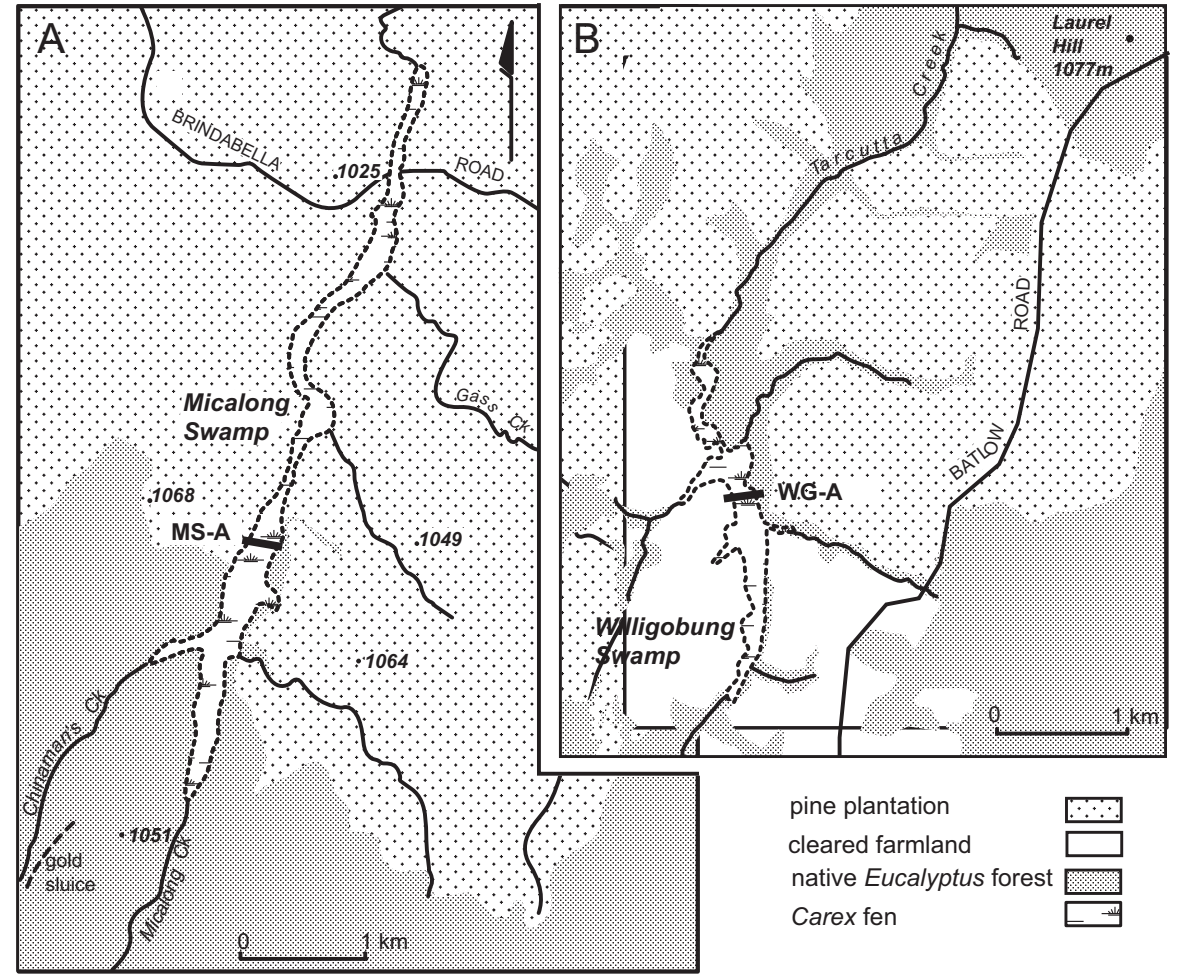




\section{Willigobung Swamp}

Willigobung (or Tarcutta) Swamp $\left(35.66^{\circ} \mathrm{S}, 148.04^{\circ} \mathrm{E}\right)$ sits on the steep western slopes of the Australian Alps in the upper Murrumbidgee Basin (Fig. 1). The valley is underlain by Silurian granite. The fen lies at $780 \mathrm{~m}$ between hills that rise to $1020 \mathrm{~m}$ and extends for $3.3 \mathrm{~km}$ down valley (Fig. 2B). Climate data from Tumbarumba Post Office, $14 \mathrm{~km}$ south at $645 \mathrm{~m}$, give mean January temperature as $20.4{ }^{\circ} \mathrm{C}$ and July as $5.2^{\circ} \mathrm{C}$, with an average annual precipitation of $980 \mathrm{~mm}$ (Bureau of Meteorology, 2013: 1885-2012).

Before European settlement fen swamp was extensive along Tarcutta Creek. In 1872, a 'large swamp' occupied $13 \mathrm{~km}$ of the valley at the confluence of Umbango and Tarcutta Creeks (The Empire, 1 April 1872). In wet seasons it became a shallow lake visited by innumerable waterfowl (Balliere, 1866). Much of the valley floor eroded in response to agricultural development or was drained for pasture in the $1930 \mathrm{~s}$, but remnants are preserved near Tarcutta township and in the headwaters of Tarcutta Creek (Page and Carden, 1988). Willigobung Swamp is now the westernmost large sedge fen in southern NSW and is regarded as degraded (Hope et al., 2012).

In 1984, the late Janet Williams described the sediments and vegetation of Willigobung Swamp (unpublished data). In comparison with other fens, the vegetation is depauperate and is dominated by sedge (Carex gaudichaudiana) with minor representation by weeds and native species, including Agrostis, Epilobium, Erodium, Hydrocotyle, Hypericum, Juncus, Lythrum and Veronica. In 1872, the catchment of Tarcutta Creek was described as 'sixty miles of finely grassed, undulating, open forest country' (The Empire, 1 April 1872). Remnants of tall eucalypt forest persist in the upper catchment, which is now dominated by Pinus radiata plantation, grazing, orchards and vineyards. Drainage to permit sheep and cattle grazing has caused drying of the lower end of the fen but the upper reaches are less affected. Some Eucalyptus stellulata around the fen may be a remnant of subalpine woodland that formed in response to cold air drainage along the valley floor.

\section{Methods}

\section{Sediments and subsampling}

A preliminary investigation of Micalong Swamp in 1982 established that organic sedimentation commenced before 14 ka (Table 1; Hope and Southern, 1983). In 1993, variations in sediment fill were defined from D-section and Livingston cores recorded at $\sim 20-\mathrm{m}$ intervals across the fen. A $5.7-\mathrm{m}$ core with 0.2-m overlap between barrel lengths was collected for detailed analysis in 1993 (MS-3; Figs 2 and 4A). Sediments were described in the field and the core stored in PVC tubes and plastic for transport. Exploratory coring of Willigobung
Swamp was carried out by Williams using identical methods to Micalong Swamp, and the deepest section selected for analysis in 1984 (WG-1: Fig. 4B).

In the laboratory 5-mm-thick slices were extracted at $10-\mathrm{cm}$ intervals except for the top $5 \mathrm{~cm}$, where $10-\mathrm{mm}$ slices were sampled at $1-\mathrm{cm}$ intervals. Subsamples of $2 \mathrm{~cm}^{3}$ were retained for pollen and charcoal analysis, and the remainder was transferred to beakers to obtain estimates of moisture and organic carbon content to provide a measure of the local site productivity and the influx of inorganic sediments. Moisture content was calculated as the difference between wet and oven-dry weight $\left(105^{\circ} \mathrm{C}\right)$ and expressed as a percentage of the total wet weight. Organic carbon in peat sediments was estimated from loss on ignition and expressed as the proportion of combustible to oven-dry sediment mass. Samples were oven dried at $105{ }^{\circ} \mathrm{C}$ for $24 \mathrm{~h}$ and combusted at $550{ }^{\circ} \mathrm{C}$ for $4 \mathrm{~h}$. Organic content of clay-rich sediments was measured by gas chromatograph following Heiri et al. (2001).

\section{Radiocarbon dating}

Samples of bulk peat from the organic sediments were radiocarbon-dated using liquid scintillation techniques at the Australian National University (ANU) following procedures outlined by Gupta and Polach (1985). Sedge fragments from the lacustrine clays underlying the fen sediments were graphitized at ANU and analysed using accelerator mass spectrometry (AMS) at the Australian Nuclear Science and Technology Organisation. Radiocarbon ages were calibrated using the Southern Hemisphere curve of INTCAL13 using Calib 7.0.0 (Stuiver et al., 2005; Hogg et al., 2013).

\section{Pollen and charcoal}

Pollen samples were prepared following standard techniques (Faegri and Iverson, 1964) and were identified with the aid of a reference collection held at the ANU. A minimum of 200 pollen grains or the whole slide was counted. Raw pollen counts were expressed as relative frequencies of the dryland pollen sum, which was based on most dryland taxa, including herbs. For Micalong Swamp this included Podocarpus, Pomaderris, Tasmannia, Eucalyptus, other Myrtaceae, Casuarinaceae, Asteraceae (Tubuliflorae and Liguliflorae), Ericaceae $<20 \mu \mathrm{m}$, Fabaceae, Proteaceae, Callitris, Poaceae, Caryophyllaceae, Plantago, Chionogentias, Astelia and fern spores (monolete and trilete). For Willigobung Swamp, Cyathea and Dicksonia were distinguished from other ferns. Aquatic pollen and spores were expressed as a percentage of the total pollen to minimize the influence of local variations in the vegetation. It was not always possible to distinguish dryland vegetation from swamp taxa because several important fen taxa (eg. Poaceae) are also well represented in the regional

Table 1. Radiocarbon ages on organic and mineral sediments at Micalong and Willigobung Swamps.

\begin{tabular}{|c|c|c|c|c|}
\hline Depth $(\mathrm{cm})$ & Sample code & Material dated & Age $\left({ }^{14} \mathrm{C}\right.$ a $\left.\mathrm{BP} \pm 1 \sigma\right)$ & Calibrated age (cal a $\mathrm{BP} \pm 1 \sigma)$ \\
\hline \multicolumn{5}{|c|}{ Micalong Core MS3 } \\
\hline $120-124$ & ANU 8827 & Bulk peat & $3330 \pm 180$ & $3540 \pm 280$ \\
\hline $276-280$ & ANU 8828 & Bulk peat & $6870 \pm 200$ & $7720 \pm 200$ \\
\hline $385-389$ & ANU 8829 & Bulk peat & $10260 \pm 230$ & $11910 \pm 490$ \\
\hline $520-529$ & ANU 8830 & AMS peat & $9900 \pm 330$ & $11340 \pm 575$ \\
\hline $559.5-560$ & ANU 8832 & AMS peat & $1030 \pm 185$ & $890 \pm 170$ \\
\hline \multicolumn{5}{|c|}{ Micalong Core MS-82 } \\
\hline $380-390$ & ANU 3342 & Bulk clayey peat & $12330 \pm 250$ & $14330 \pm 470$ \\
\hline \multicolumn{5}{|c|}{ Willigobung Swamp WSA } \\
\hline $360-375$ & ANU 4384 & Peat & $5770 \pm 120$ & $6530 \pm 130$ \\
\hline $515-530$ & ANU 4385 & Peaty clay & $9420 \pm 110$ & $10580 \pm 170$ \\
\hline
\end{tabular}


vegetation. Shrub Ericaceae was excluded from the dryland pollen sum as Epacris species are often prominent in swamp communities. All representatives of the Apiaceae-Araliaceae family were also excluded; high frequencies of ApiaceaeAraliaceae pollen suggested a dominantly local source, probably the aquatic Hydrocotyle.

Relative pollen frequencies were determined and pollen diagrams were constructed using TILIA 1.7.14 (Grimm, 1990). The pollen diagram was separated into zones using CONISS, which uses a multivariate method for quantitative definition of pollen frequency data (Grimm, 1987). Slides prepared for pollen analysis were used to obtain quantitative estimates of charcoal (8-100 $\mu \mathrm{m}$ - microcharcoal). An automated counting program was used to estimate the area of charcoal per slide, which identifies dark material in a specified band of light densities but omits extremely opaque objects that might be minerals. The estimate of charcoal area is reported as $\mathrm{mm}^{2}$ $\mathrm{mL}^{-1}$ of original sediment (Dolman, 1991).

\section{Results}

\section{Micalong Swamp \\ Stratigraphy and chronology}

Moisture, organic carbon and charcoal volume are given in Fig. 3. The depth of the valley fill could not be determined, but the corer penetrated into rounded, fine gravels fining upwards to sands and clayey sands (Fig. 4). The top $\sim 30 \mathrm{~cm}$ below the surface peat mat $(\sim 10 \mathrm{~cm})$ was not recovered owing to high moisture content. At the time of sampling the water table was at the surface with surface flow across the swamp at $0.12 \mathrm{~m} \mathrm{~s}^{-1}$.

The radiocarbon age for MS82 indicates that organic sedimentation in the valley had commenced before $14.3 \mathrm{ka}$, although the disparity between the basal organic sediment ages of cores MS82 and MS3 may indicate erosion by a migrating stream. The AMS radiocarbon ages on sedge fragments in the underlying sandy clays yielded younger ages than the basal organic sediment ages of 11.9 and $14.3 \mathrm{ka}$ (Table 1), which may have been contaminated by organic sediments during coring. Dating basal sediments has been an ongoing issue with alpine and sub-alpine fens in south-east Australia, but minor contamination would have little effect on the bulk peat ages. The basal clay ages have been excluded from the age-depth model, which used the mid-point of calibrated date ranges for a linear regression with sample depth as the independent variable. Some additional uncertainty in ages $<3.5 \mathrm{ka}$ is due to higher moisture content and lower compaction of the surface mat. The appearance of exotic pollen above $10 \mathrm{~cm}$ reflects European land uses that date to about AD 1850 (100 cal a BP).

While speculative, the model gives a near linear relationship with depth $\left(r^{2}=0.99\right)$, although the changes in mineral content suggest that the sedimentation rate was not constant and may include gaps. Nevertheless the age model provides an approximate age for the valley sedimentation and environmental changes. Downward extrapolation of the overall sedimentation rate places the onset of fine-textured sedimentation at $\sim 16.1 \mathrm{ka}$.

\section{Biostratigraphy}

Dryland pollen counts ranged from 38 to 157 with poor preservation giving counts $<50$ in three samples (Fig. 5). The record was divided into five zones based on the CONISS results and the proportion of major dryland pollen types.

Zone MS I $(570-520 \mathrm{~cm} ;<16.1 \mathrm{ka})$. Sediments are dominantly sub-angular yellow-brown sands below $540 \mathrm{~cm}$, overlain by beds of reddish yellow and grey sandy clays with abundant Cyperaceae above $532 \mathrm{~cm}$. Organic carbon is mostly $<1 \%$ and charcoal increases from 4 to $16 \mathrm{~mm}^{2} \mathrm{~mL}^{-1}$.

Herbaceous pollen dominates the pollen spectra. Poaceae reaches values of $80 \%$ and exhibits a general decline in favour of Asteraceae, but both reach their maximum representation in this zone with pollen of other herbs, including Astelia, Plantago and Chionogentias, occasionally recorded. Eucalyptus, the most numerous woody taxon, fluctuates around $15 \%$ of the dryland pollen. Tasmannia and Podocarpus recur at proportions $<3 \%$. Casuarina and Chenopodiaceae are present at uniformly low levels. Shrub Ericaceae become relatively numerous at around 5\% towards the top of the zone and Proteaceae and Fabaceae appear in minor proportions. Fern spores are consistently $<5 \%$. The swamp flora is dominated by Cyperaceae, which declines from 20 to $5 \%$ at the top of the zone. Myriophyllum and Restionaceae

${ }^{14} \mathrm{C}$ ages Sediments
(cal a BP)

\section{Time Depth} (cal a BP) $(\mathrm{cm})$

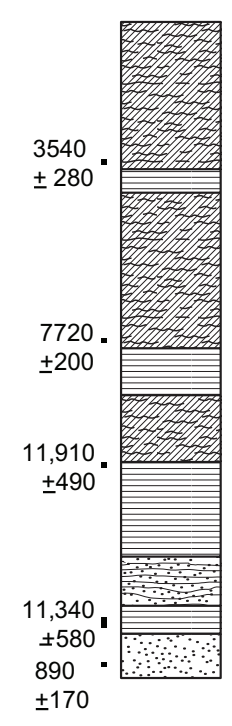

Figure 3. Sediments, water content, loss on ignition and charcoal counts for core MS3 at Micalong Swamp. See Fig. 4 for key to sediments.

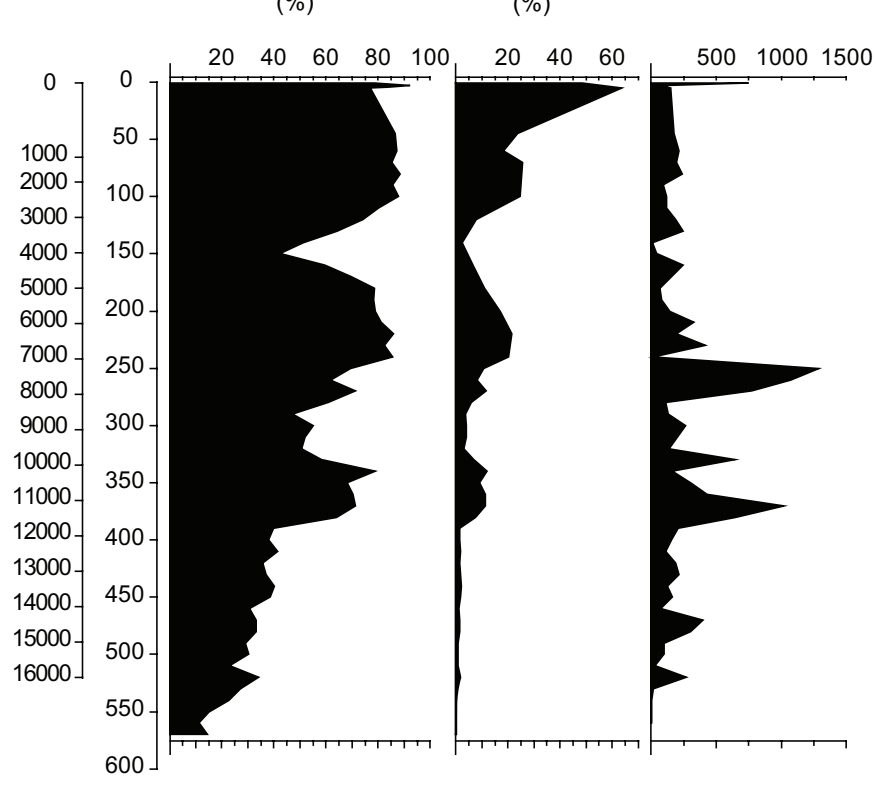


A

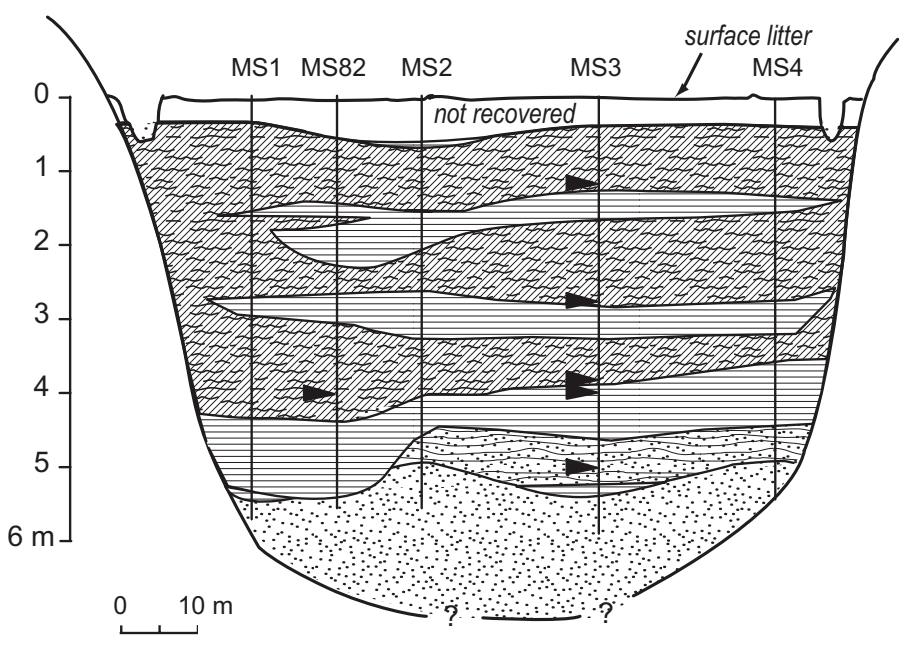

Key to sediments

$\begin{array}{ll} & \text { fibrous sedge peat } \\ & \text { peaty clay } \\ & \text { clayey sand } \\ & \text { gravelly coarse sand } \\ & { }^{14} \mathrm{C} \text { sample }\end{array}$

B

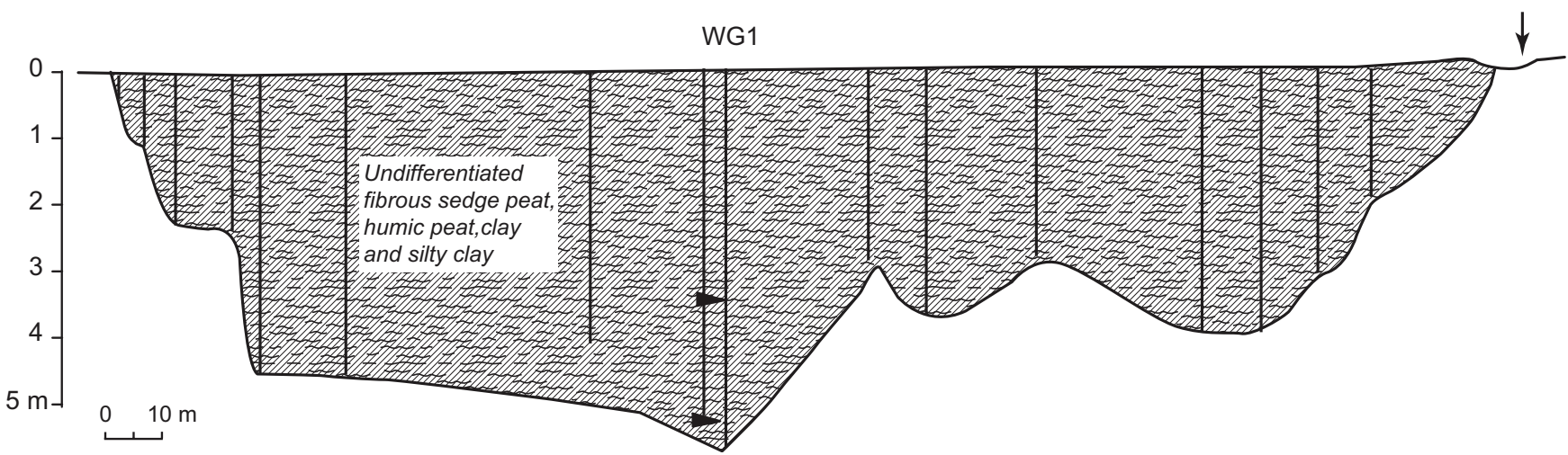

Figure 4. Stratigraphic cross-sections at (A) Micalong Swamp (MS-A) and (B) Willigobung Swamp (WG-A) (Fig. 2).

and swamp shrubs species of Myrtaceae and Ericaceae $>20 \mu \mathrm{m}$ comprise $<5 \%$ of the total pollen sum.

Zone MS II (520-335 cm; 16.1-10.0 ka). Sediments change abruptly from grey clay with lenses of sandy clay and gravelly clay to black, fibrous peaty mud at $386 \mathrm{~cm}$, accompanied by an increase in organic carbon content from 1 to $11 \%$. Charcoal increases to $170 \mathrm{~mm}^{2} \mathrm{~mL}^{-1}$ with a pronounced peak at $380-360 \mathrm{~cm}$.

Pollen spectra are dominated by Asteraceae and Poaceae, which alternate in dominance until $385 \mathrm{~cm}$ when pollen of Casuarinaceae and Eucalyptus increases to 10 and 20\% of the dryland sum, respectively. Podocarpus disappears from the record, and the proportions of shrub species of Ericaceae and Myrtaceae decrease. Tasmannia and Fabaceae frequencies are higher in this zone. Caryophyllaceae adds to the herb flora and becomes relatively prolific in the upper part of the zone. Fern spores are consistently $\sim 4 \%$. Substantial changes in the swamp flora are apparent from the steady increase in Cyperaceae after $530 \mathrm{~cm}$, and peaks in Hydrocotyle and Apiaceae-Araliaceae accompany the change to more organic sedimentation.

Zone MS III (335-110 cm; 10.0-2.7 ka). Sediments are brown and grey-brown fibrous peaty mud with regular, visible changes in humification and clay content. Organic carbon content reaches $21 \%$ in organic sediments and 3-5\% in clayey sediments. Charcoal reaches $1290 \mathrm{~mm}^{2} \mathrm{~mL}^{-1}$ between 250 and $270 \mathrm{~cm}$, then falls to $\sim 160 \mathrm{~mm}^{2} \mathrm{~mL}^{-1}$.
An increase in Eucalyptus occurs between 270 and $140 \mathrm{~cm}$, where it exceeds $50 \%$ of the dryland pollen at the expense of Poaceae and, to a lesser extent, Asteraceae. Casuarinaceae achieves several peaks accompanied by higher proportions of shrub and small tree species of Myrtaceae and Proteaceae, and monolete and trilete fern spores, especially in the lower half of the zone where they reach proportions of 10 and $20 \%$, respectively. Tasmannia peaks in the upper part of the zone, where Podocarpus and Pomaderris also reappear. Shrub species of Ericaceae appear sporadically. Chenopodiaceae declines to $<5 \%$, but increases, together with Callitris, towards the end of the zone. In the fen, Cyperaceae fluctuates together with Hydrocotyle, alternating with Myriophyllum, Restionaceae and Epacris.

Zone MS IV (110-45 cm; 2.7-0.6 ka). Sediments are dark brown fibrous peaty mud with root and leaf macrofossils. Organic content is $<25 \%$ and charcoal averages $170 \mathrm{~mm}^{2}$ $\mathrm{mL}^{-1}$. This zone is marked by a substantial decline in Eucalyptus to proportions $<20 \%$ and substantial increases in Asteraceae, Poaceae, Callitris and Chenopodiaceae. Tasmannia and Ericaceae disappear from the record. Proteaceae, Podocarpus and Fabaceae are occasionally recorded. Of the herbs, only Caryophyllaceae makes an appearance in this zone and fern spores fall to insignificant levels. A single grain of introduced Pinus is attributed to contamination. Cyperaceae dominates the aquatic flora with minor Myriophyllum, Restionaceae, Hydrocotyle and Epacris. 


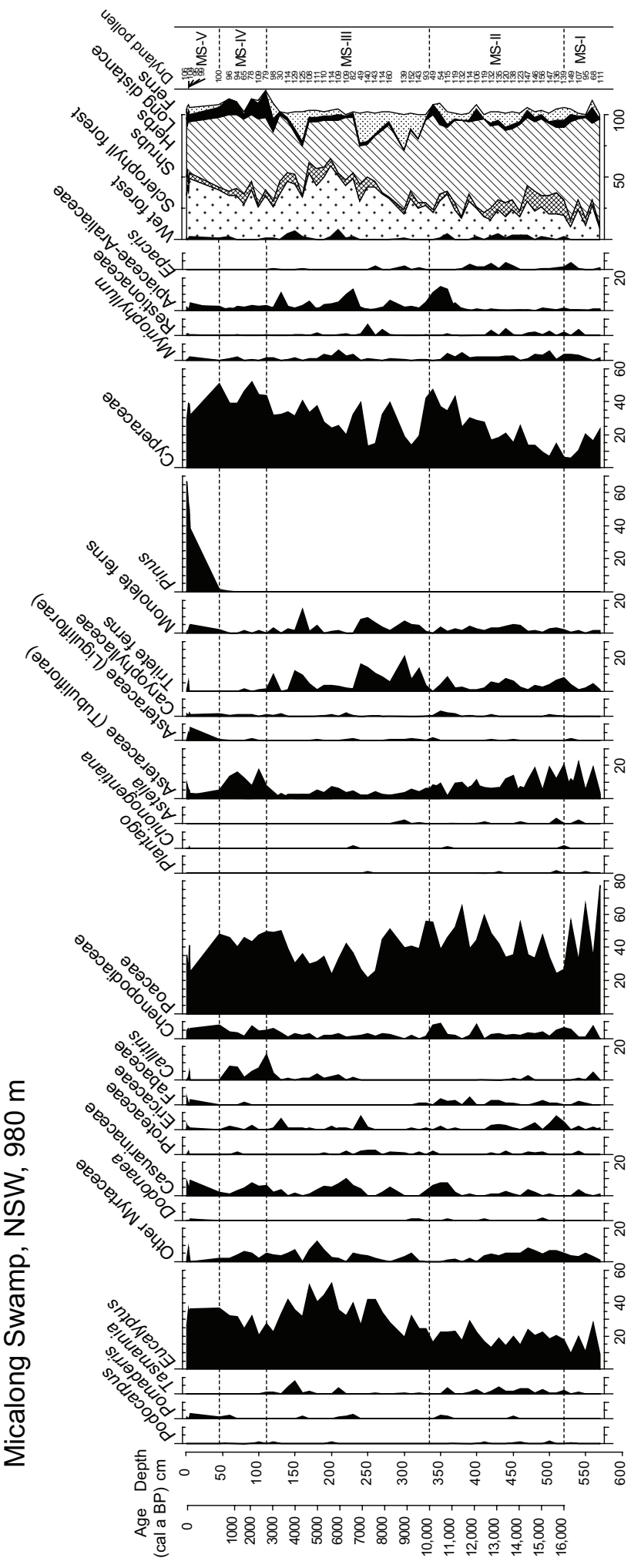

Figure 5. Relative frequencies of pollen and spores, Micalong Swamp, NSW.

Zone MS V (45-0 cm; $0.6 \mathrm{ka}-A D$ 1993). Sediments are dark brown fibrous peaty clay with root and leaf macrofossils with a watery zone causing poor recovery between 40 and $10 \mathrm{~cm}$. Organic carbon content reaches $70 \%$ at the surface, where charcoal peaks at $750 \mathrm{~mm}^{2} \mathrm{~mL}^{-1}$, above previous levels of $\sim 175 \mathrm{~mm}^{2} \mathrm{~mL}^{-1}$. Eucalyptus pollen increases to $35 \%$ and Asteraceae declines to $<10 \%$. Cyperaceae pollen dominates the aquatic flora. Shrub species of Myrtaceae are not recorded. Chenopodiaceae remains at 5\%. Introduced Pinus and Asteraceae Liguliflorae appear in the top $2 \mathrm{~cm}$.

\section{Willigobung Swamp}

\section{Stratigraphy and chronology}

Sediments, organic carbon and charcoal volumes for Willigobung Swamp are given in Fig. 6. The age-depth model was constructed from the two calibrated radiocarbon ages of $6.5 \mathrm{ka}(\sim 368 \mathrm{~cm})$ and $10.6 \mathrm{ka}(\sim 523 \mathrm{~cm})$ (Table 1$)$ following the same procedure as for Micalong Swamp. European pollen is found only in the top few centimetres so $5 \mathrm{~cm}$ is considered to represent $100 \mathrm{cal} \mathrm{a} \mathrm{BP.} \mathrm{If} \mathrm{a} \mathrm{constant} \mathrm{sedimentation} \mathrm{rate}$ between these points is assumed the mean sedimentation rates of the lower core is $0.38 \mathrm{~mm} \mathrm{a}^{-1}$ increasing to $0.65 \mathrm{~mm}$ $\mathrm{a}^{-1}$ after $6.5 \mathrm{ka}$. The basal age of $\sim 11.6 \mathrm{ka}$ is based on extrapolation. As for Micalong Swamp this simple linear model provides an indication of the age of individual levels but may conceal changes in sedimentation rate or gaps in the record.

\section{Biostratigraphy}

Dryland pollen counts range from 32 to 229 with five samples recording counts $<50$ (Fig. 7). The pollen record was divided into four zones based on the CONISS results.

Zone WG I $(540-495 \mathrm{~cm} ;<11.2-9.9 \mathrm{ka})$. Basal sediments comprise grey clay with thin beds of fibrous peat. Organic content averages $20 \%$ and charcoal averages $64 \mathrm{~mm}^{2} \mathrm{~mL}^{-1}$. Cyperaceae and Apiaceae-Araliaceae dominate the fen pollen. The dryland pollen sum comprises $\sim 50 \%$ herbs, mostly Asteraceae and Poaceae. Monolete and trilete fern spores excluding the tree ferns Cyathea and Dicksonia represent a further $7-28 \%$. Eucalyptus pollen are $>10 \%$ with small but significant sclerophyll elements: Casuarinaceae $(<7 \%)$, shrub Myrtaceae $(<11 \%)$ and, at the end of the zone, Dodonaea. Levels of $3-5 \%$ chenopod pollen are recorded.

Zone WG II (495-331 cm; 9.9-5.9 ka). Sediment is grey clay with $\sim 10 \%$ organic content becoming more organic above $400 \mathrm{~cm}$. Charcoal averages $62 \mathrm{~mm}^{2} \mathrm{~mL}^{-1}$. Greater diversity in the bog pollen is marked by the decline in Cyperaceae and Apiaceae-Araliaceae and consistent representation of $\mathrm{LyCO}$ podium. The zone is characterized by moderate levels of wet forest elements Tasmannia (5\%) with tree and ground ferns comprising 3 and $39 \%$ of the dryland pollen, respectively. Eucalyptus frequencies average $12 \%$ and Dodonaea is not

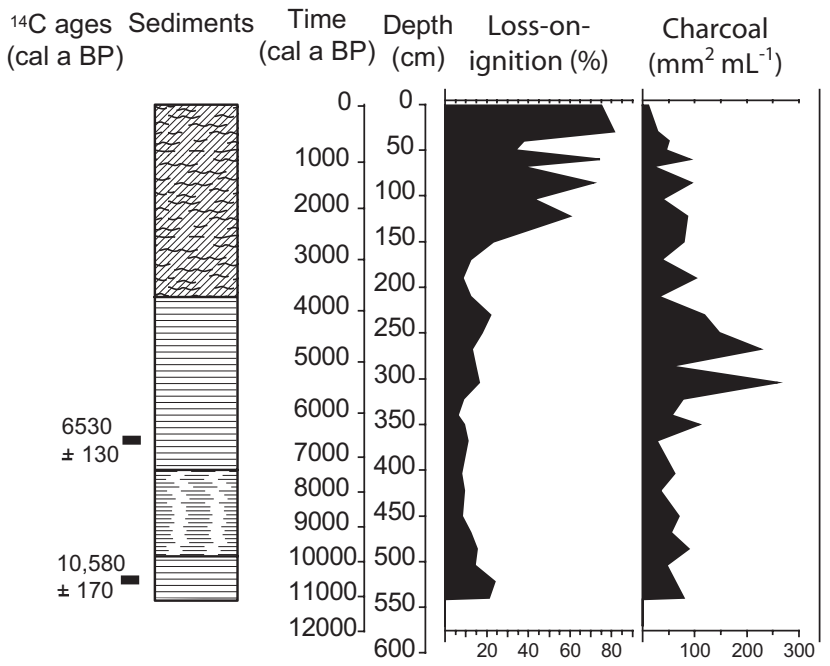

Figure 6. Sediments, loss-on-ignition and charcoal counts for Willigobung Swamp. See Fig. 4 for key to sediments. 


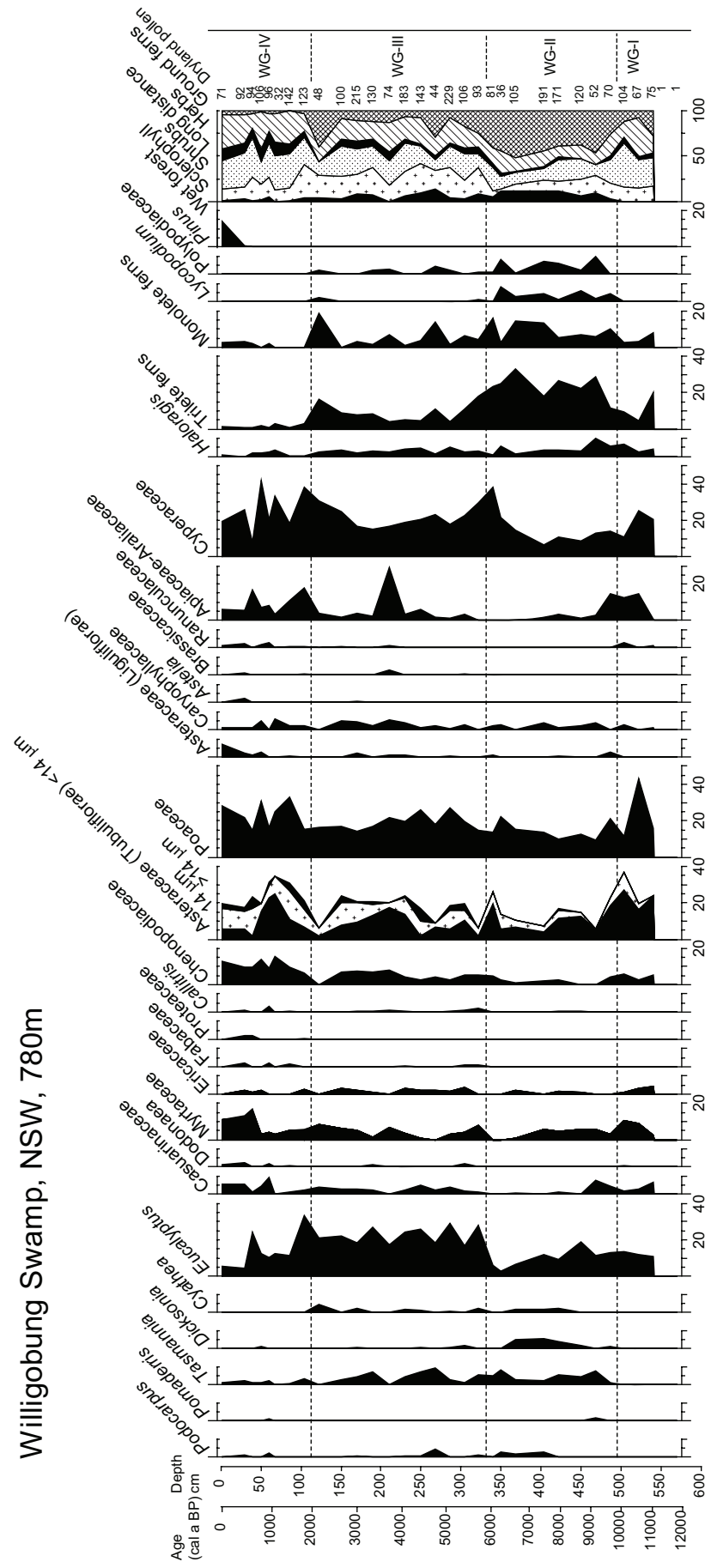

Figure 7. Relative frequencies of pollen and spores, Willigobung Swamp, NSW.

recorded. Poaceae and Asteraceae fall to $\sim 15 \%$ and chenopods fall to $3 \%$.

Zone WG III $(331-113 \mathrm{~cm} \mathrm{5.9-2.0} \mathrm{ka).} \mathrm{Organic} \mathrm{clay} \mathrm{gives}$ way to fibrous sedge peat above $215 \mathrm{~cm}$. Loss-on-ignition percentages increase from $\sim 15$ to $60 \%$ at the top of the zone, except between 210 and $170 \mathrm{~cm}(3.1-2.5 \mathrm{ka})$ when they fall to $\sim 10 \%$. Charcoal falls from 260 to $\sim 70 \mathrm{~mm}^{2} \mathrm{~mL}^{-1}$ above $210 \mathrm{~cm}$. Cyperaceae dominates the aquatic pollen but Apiaceae-Araliaceae proportions are intermittently higher than in the preceding zone. Lycopodium virtually disappears. Sclerophyll elements Casuarina and Myrtaceae dominate the dryland pollen with Eucalyptus frequencies averaging 22\% and Ericaceae 2\%. Traces of Cyathea appear but Dicksonia is not present above $250 \mathrm{~cm}$ (4.4 ka). Other trilete and monolete ferns average $13 \%$, rising to $40 \%$ at $122 \mathrm{~cm}$. Chenopod proportions are slightly higher (5\%).

Zone WG IV (113-0 cm; 2.0 ka BP - AD 1984). Fibrous sedge peat continues to the surface. Charcoal declines to $\sim 50 \mathrm{~mm}^{2} \mathrm{~mL}^{-1}$ above $50 \mathrm{~cm}$ (625 a BP). The aquatic pollen is dominantly Cyperaceae and Apiaceae-Araliaceae with apparently low diversity. Herb pollen exceeds forest pollen in the dryland sum with Poaceae at 23\%. Frequencies of Asteraceae decrease from $>30$ to $\sim 20 \%$ above $50 \mathrm{~cm}$. Eucalyptus decreases to $13 \%$ with continuing representation by Casuarinaceae and Myrtaceae. Above $70 \mathrm{~cm}$ chenopod frequencies rise to $\sim 12 \%$. An influx of Pinus and Poaceae is apparent near the surface.

\section{Late Quaternary vegetation and environmental reconstruction}

Rounded fluvial gravels and sands at the base of the Micalong infill indicate a sandy gravel-bed river excavating a narrow floodplain before $\sim 16.1 \mathrm{ka}$. Cyperaceae with Epacris heath probably occupied wet ground along the banks with Myriophyllum occupying shallow pools in the valley bottom. High proportions of Poaceae pollen suggest a local source, possibly from well-grassed, steep slopes surrounding the site at this time. Herbs constitute $80-90 \%$ of the dryland pollen, suggesting an open or treeless landscape. The dominance of Asteraceae and Poaceae with subalpine and alpine indicator species Astelia, Plantago, Caryophyllaceae and ApiaceaeAraliaceae suggests alpine steppe or tussock grassland that was gradually replaced by alpine herbfield or open shrubland. Pollen taxa suggest a mosaic of alpine heath, including shrub forms of Tasmannia and Podocarpus, Ericaceae, Asteraceae and Myrtaceae in closed heathlands similar to that common along rocky waterways up to $1950 \mathrm{~m}$ Australian Height Datum (AHD) in the Snowy Mountains (McDougall and Walsh, 2007). Dwarf forms of Tasmannia, Epacris, Richea and shrub Proteaceae (e.g. Orites and Grevillea) may have formed open heathland with areas of grassland in the upper catchment, but the efficient dispersal characteristics of Podocarpus raises the possibility of fjaeldmark or heath communities occupying the summit of higher ranges. The open landscape at the time would have made the fen sensitive to extra-local and regional vegetation, and the low frequencies of Eucalyptus, together with Callitris and chenopods, may reflect drier forest occupying lowlands to the west. The low occurrence of charcoal is consistent with low fire frequencies in the alpine zone (McDougall and Walsh, 2007). Sediments of this age were not recovered from Willigobung Swamp.

Finer sediments with abundant sedge macrofossils accumulated at Micalong Swamp after $16.1 \mathrm{ka}$ (MS II), suggesting that mineral sediments were deposited in a shallow lake or sedge fen that flooded episodically or seasonally, possibly by snowmelt. Higher levels of Myriophyllum also suggest slow flowing or shallow water. A steep rise in Cyperaceae pollen together with an increase in organic sedimentation marks the onset of warmer conditions. At Willigobung, a similar sedimentological change suggests that the transition occurred before $11.2 \mathrm{ka}$ with an intermittent return to shallow lake or fen sedimentation. Apiaceae-Araliaceae and Caryophyllaceae pollen appear to have contributed to the marginal fen communities more than at present. Both families are considered alpine and subalpine indicators, but several species are widespread at lower altitudes and both are found on the site today in damp ground within the marginal Sphagnum bog (Hope and Southern, 1983). While these may have formed an 
important part of regional herbfield communities, dominantly local dispersal of both pollen types implies a prolific local distribution. At Micalong Swamp, parallel increases in species of Hydrocotyle, a mat-forming herb commonly found in boggy areas, supports this reconstruction. Substantial increases in the abundance of Cyperaceae point to the development of closed sedgeland, although the absence of standing water is indicated by the almost complete disappearance of Myriophyllum towards the end of this zone.

Through the remainder of the Lateglacial, the regional vegetation at Micalong Swamp was dominantly grassland, but the sustained increase in Eucalyptus suggests woodland expanded nearby or on higher slopes above the frost hollow. The fen was probably surrounded by a marginal heathland that included Epacris. Ericaceae-Podocarpus heath may have occupied higher, exposed slopes. Rare appearances of Pomaderris pollen may indicate a presence along the stream in a similar association to bog communities along drainage lines in the Barrington Tops at elevations up to $1500 \mathrm{~m}$ (Whinam and Chilcott, 2002). At a lower elevation, high proportions of herb pollen are recorded at Willigobung Swamp by $11.2 \mathrm{ka}$ (WG I), but significant levels of Casuarinaceae and Dodonaea suggest an open sclerophyll woodland was already established on the slopes. Casuarinaceae species may have expanded along waterways near the site, possibly Casuarina cunninghamii, which grows along streams nearby at elevations up to $1000 \mathrm{~m}$. Casuarinaceae species are also common on skeletal or shallow soils on drier slopes to the west, including Allocasuarina verticellata, which appears in pure stands or with Eucalyptus in grassy woodland up to elevations of $900 \mathrm{~m}$.

After $10.0 \mathrm{ka}$, clear evidence for forest cover at Micalong Swamp is suggested by the rise in Eucalyptus and Casuarinaceae, confining Asteraceae and other herbs to the damp fringes of the bog. Shrub species of Proteaceae and Myrtaceae may have formed part of the forest, but high frequencies of Poaceae suggest a grassy understorey persisted until $7.8 \mathrm{ka}$. The tree fern Dicksonia may have been a pioneer in the development of wet forest, but alternative sources for the trilete ferns include understorey ferns Polystichum or Calochlaena. Monolete ferns possibly present include Blechnum, Adiantum (maidenhair), Pteridium and Gleichenia, which today are common along stream margins. Higher rates of mineral sedimentation from 9.7 to $8.2 \mathrm{ka}$, and from 3.9 to 3.2 $\mathrm{ka}$, indicate a return to episodic flooding, possibly owing to increases in rainfall since forest was established by this time.

Shrub-rich forest, indicated by an expansion of tree and ground ferns, appears to have reached its maximum extent at Micalong Swamp between 10.0 and $6.8 \mathrm{ka}$. Wetter conditions are also suggested by the flooding of the fen at 9.7-8.2 ka. The periodic alternation of Casuarinaceae-Poaceae with Eucalyptus-Myrtaceae and ferns suggests that open Eucalyptus-Allocasuarina forest alternated with a denser, more structured Eucalyptus forest in drier periods throughout the Holocene. Visible charcoal layers in some of the clay layers could indicate that fire contributed to higher sediment yields. Larger peaks in charcoal in montane sedge fens may indicate more frequent burning of the bog or catchment during extended droughts. At Willigobung, the development of wet forest around the same time at $9.9 \mathrm{ka}$ is marked by an expansion of tree and ground ferns and Tasmannia. Shallow lake sedimentation is apparent from 9.9 to $7.5 \mathrm{ka}$. After $5.9 \mathrm{ka}$, wet forest elements decline and a noticeable increase in charcoal suggests higher burning frequencies in a tall open forest.

Around $2.7 \mathrm{ka}$, a substantial decline in Eucalyptus at Micalong Swamp is accompanied by an increase in Asteraceae and Poaceae pollen, suggesting forest retreat. The substantial frequencies of Callitris pollen and, to a lesser extent, Casuarinaceae imply an eastward expansion of dry sclerophyll forest, with more open conditions at the fen making it receptive to Chenopodiaceae. Charcoal counts do not support a change in biomass burning at this time, but charcoal levels partly reflect the sedimentation rate; highresolution macrocharcoal analysis is needed to compile the fire recurrence intervals through time at both of these sites. Floristically, the fen is depauperate and is dominated by Cyperaceae. The high organic content of the sediments is consistent with slow decay in cooler conditions. By 0.9 ka, Eucalyptus forest had returned to previous levels, but high Poaceae frequencies and the decline in shrub pollen suggest open woodland. The late Holocene is a more complex interval at Willigobung Swamp. A wetter period marked by an increase in fern spores at $4.4 \mathrm{ka}$ is accompanied by an increase in mineral sedimentation, possibly from seasonal flooding of the fen. This is followed by a period of increased Poaceae and Asteraceae between 1.3 and $0.8 \mathrm{ka}$. More open conditions at this time are suggested by the increase in chenopod frequencies. At both sites, the appearance of Pinus pollen marks the regional establishment of conifer plantations, and the proliferation on the bog surface of introduced herbs of Asteraceae (Liguliflorae), such as Hypochoeris radicata.

\section{Discussion}

Micalong and Willigobung Swamps are the only vegetation sequences extending into the Pleistocene yet reported from the montane western slopes of the Southern Tablelands. In general terms, they present similar features to sites from similar altitudes on the eastern slopes, such as Nursery Swamp (1092 m, Hope, 2006), Bega Swamp (1080m) (Donders et al., 2007) and Bogong Creek Swamp (1005 m, G. Hope, unpublished data). Basal ages on seeds or charred plant remains in the sandy clays of these three are 14 $260 \pm 250,15850 \pm 280$ and $16420 \pm 410$ cal a BP, respectively, providing support for the tentative age model for Micalong Swamp.

Their records can also be compared with several shrubby subalpine bogs at higher altitudes extending from the Snowy Mountains (Martin, 1986, 1999) through the Blue Mountains (Robbie and Martin, 2007) and the Barrington Tops at ca. $1000 \mathrm{~m}$ (Dodson, 1987). Detailed records from the submerged canyon of the Murray River on the South Australian continental shelf have a close affinity to terrestrial records in south-east Australia (MD03-2611: Calvo et al., 2007; Gingele et al., 2007; Lopes dos Santos et al., 2013). On land, highresolution records of the Holocene are now available from Lakes Keilambete and Gnotuk (Wilkins et al., 2013), together with a high lake level record from Lake George (Fitzsimmons and Barrows, 2010).

The structure of Lateglacial vegetation assemblages is difficult to determine from pollen records owing to the appearance of well-represented plant families and genera, such as Grevillea, Podocarpus, Myrtaceae and Asteraceae, in both alpine and montane tracts. Proportions of $<10 \%$ Eucalyptus pauciflora (snow gum) pollen have been reported in 100-m clearings within modern snow gum woodland, suggesting that its dispersal characteristics are poorer than montane eucalypts, which are well dispersed upslope and regionally, and may produce high frequencies of pollen above the treeline (Martin, 1986, 1999). Extensive subalpine woodland on high plateau surfaces may therefore be invisible in pollen records, and the rise of Eucalyptus in Lateglacial spectra may reflect the approach of montane or drier lowland forest communities rather than migration of the treeline. 
Most analysts infer treeless conditions in the south-east highlands above $600 \mathrm{~m}$ AHD during the Last Glacial Maximum (LGM) and Lateglacial (e.g. Singh and Geissler, 1985; Dodson, 1986; Hope et al., 2004). Below this elevation, open woodland persisted at coastal and inland sites (Dodson and Wright, 1989; Williams et al., 2006). A lower limit to the climatic treeline in southern NSW is defined by Mountain Lagoon, which records forest up to $500 \mathrm{~m}$ elevation on the eastern ranges at the LGM (Robbie and Martin, 2007), but lower precipitation, low carbon dioxide and higher wind speeds may have contributed to treelessness on the NSW tablelands (Dodson, 1998; Hope et al., 2004).

Micalong and Willigobung straddle the LGM treeline, hypothesized to lie at $975 \mathrm{~m}$ based on the former extent of periglacial landforms at $35^{\circ} \mathrm{S}$ (Galloway, 1965). The modern treeline in the southern Australian Alps lies at 1700-1800 m and is defined by the $10{ }^{\circ} \mathrm{C}$ mean January isotherm (Slatyer, 1989), but descends northwards to $<1300 \mathrm{~m}$ on the exposed plateau surface near Kiandra where January mean temperature is $13.4{ }^{\circ} \mathrm{C}$ (Bureau of Meteorology, 2013). Treeless conditions at Micalong Swamp imply that summer temperatures were at least $4-7^{\circ} \mathrm{C}$ lower (making an allowance for elevation), but an expansion of the grassy frost hollow would be produced by a reduction of as little as $1-2{ }^{\circ} \mathrm{C}$ in mean summer temperature.

The regional pattern of forest development in the late Pleistocene is consistent with the pattern of temperature emerging from marine records of sea surface temperature (SST) in south-east Australia. Beginning at 17-18 ka, a rapid increase in SST of $4{ }^{\circ} \mathrm{C}$ is apparent from MD03-2611 and in the Tasman Sea (Calvo et al., 2007; RS147-GC7: Lopes dos Santos et al., 2013). Radiocarbon ages on basal organic sediments overlying glacial and periglacial rubble suggest that conditions were sufficiently warm for peat development by $18.2 \mathrm{ka}$ in the Australian Alps (Costin, 1972), with the final retreat of glaciers effected between 16.8 and $15.9 \mathrm{ka}$ (Barrows et al., 2001). This may have been responsible for a regional expansion of forest around $18 \mathrm{ka}$ in the Barrington Tops (Sweller and Martin, 2001). The vegetation was probably subalpine at Micalong Swamp by $15.8 \mathrm{ka}$, although chronological uncertainties in the basal sediments make it difficult to be precise about the timing.

A return to cooler conditions or an interruption in the warming trend was registered by lower SST during the Antarctic Cold Reversal (14-12.5 ka) between 16 and $13 \mathrm{ka}$ in the Australian coastal waters and Southern Ocean (Calvo et al., 2007; Lopes dos Santos et al., 2013). On land, high illite levels in the Murray Canyon indicate enhanced fluvial activity between 15 and $13 \mathrm{ka}$ and coincide with active migration of snowmelt-engorged rivers in the Murrumbidgee and Goulburn catchments (Page et al., 1996; Gingele et al., 2007). Regional pollen records show no evidence for vegetation change, but the prolonged cold interval may have contributed to the late appearance of forest in most montane records.

After $13 \mathrm{ka}$, a second rapid increase in SST is apparent in MD03-2611 and by 11 ka temperatures had risen to modern levels (Fig. 1; Calvo et al., 2007; Lopes dos Santos et al., 2013). Between 12 and 11 ka the East Australian Current, which conveys tropical waters down the east coast of Australia, extended rapidly southward, increasing SST regionally (Bostock et al., 2006). With the flooding of the Bass Strait at $9.6 \mathrm{ka}$, modern ocean circulation was established (Blom and Alsop, 1988). The combined effect of these changes would have been to increase tropical heat transport to southern and south-east Australia, increasing moisture levels and reducing continentality at inland locations.
A range of terrestrial evidence suggests that the Last Glacial-Interglacial Transition was relatively arid in the Tablelands. River flows in the Murray Basin registered at MD03-2611 were low between 12 and 14 ka (Gingele et al., 2007), and high quartz and titanium levels in the same core indicate a return to arid conditions (De Deckker et al., 2012). Optically stimulated lumiscence ages on shorelines at Lake George suggest lake levels were low between 14 and $10 \mathrm{ka}$ (Fitzsimmons and Barrows, 2010). Mountain Lagoon remained a shallow fen until deeper water appeared around 10 ka (Robbie and Martin, 2007). Pollen records from NSW suggest forest developed later in western compared with eastern sites, possibly owing to a steep E-W precipitation gradient. On the eastern ranges, Eucalyptus woodland extended up to $1000 \mathrm{~m}$ at Gooches Crater by at least $14.5 \mathrm{ka}$ (Black and Mooney, 2006). Open woodland was already established at higher elevations on the Barrington Tops by $12.9 \mathrm{ka}$ and cool temperate rainforest communities were established by $10.2 \mathrm{ka}$ (Dodson et al., 1986). In the western ranges, montane forest developed around $10.0 \mathrm{ka}$ and wet forest did not expand until $\sim 8-9$ ka. Forest also developed later in sites such as Bega Swamp located near modern rainshadows, which may have been enhanced at this time. There, forest developed at $10.5 \mathrm{ka}$, and wet forest did not expand until $7.5 \mathrm{ka}$ (Hope et al., 2004; Donders et al., 2007).

The vegetation records from the Southern Highlands tend to produce a picture of stable climates through the Holocene, although more sensitive indicators of climate change indicate effective precipitation was variable after $10 \mathrm{ka}$ (Kemp et al., 2012; Wilkins et al., 2013). At Lake George the highest Holocene shorelines occur at 10-8 ka (Fitzsimmons and Barrows, 2010), but modelled lake levels from the composite Keilambete-Gnotuk record suggest high lake levels were limited to $\sim 1000$ years centred at 7.2 ka (Wilkins et al., 2013). In pollen records this interval is usually characterized by consistent representation of Pomaderris, indicating the development of more extensive wet forest (the 'Pomaderris

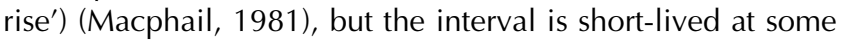
sites such as Club Lake, which today lies above the montane forest zone (Martin, 1986). Pomaderris is virtually absent at both Micalong and Willigobung, suggesting that precipitation remained marginal for wet forest, but variations in effective precipitation may be the cause of alternations between drier and wetter forest elements at Micalong Swamp.

The return to subalpine woodland or daisy-rich grassland at Micalong Swamp between 2.7 and 0.9 ka implies a return to colder conditions, an expansion of subalpine woodland and/ or the valley bottom frost hollow. The change is not apparent at Willigobung, $200 \mathrm{~m}$ lower in elevation, but support for regional cooling comes from renewed periglacial action in the Australian Alps between 3.2 and 1.4 ka (Costin, 1972; Martin, 1986) and in a general resurgence in bog growth between 4.1 and $2.5 \mathrm{ka}$ (Macphail and Hope, 1985; Dodson et al., 1986). A phase of increased hillslope instability in the Southern Tablelands between 3.1 and 1.1 ka may reflect an increase in cold climate weathering at higher elevations (Williams, 1978; Eriksson et al., 2006). Elevated lake levels at Lakes Keilambete, Gnotuk and George at 4.0-2.1 ka (Fitzsimmons and Barrows, 2010; Wilkins et al., 2013) suggest cooling rather than greater aridity was responsible for the environmental changes at this time.

\section{Conclusions}

Micalong and Willigobung Swamps provide apparently complete records of vegetation from Lateglacial times to the present, and are the first vegetation records from the 
montane, western slopes of the NSW Southern Tablelands. Pollen records suggest the development of full forest cover was established at $\sim 10 \mathrm{ka}$, and was delayed $2-3 \mathrm{ka}$ behind some sites in the coastal ranges. Wet forest expansion occurred relatively late at 9-8 ka and remained limited throughout the Holocene. Evidence for a neoglacial cooling at higher elevations between 2.7 and $0.9 \mathrm{ka}$ is consistent with other terrestrial records in south-eastern Australia. Highresolution analysis of macrocharcoal, supported by higher resolution dating based on identified material such as seeds or charcoal, in these and other regional records is needed to explore the effects of changing fire regimes on vegetation.

Acknowledgements. We are grateful to the late John Head for having graphitized the AMS samples and to Ewan Lawson and ANSTO for providing the final AMS radiocarbon ages. The late Janet Williams studied the stratigraphy of Willigobung Swamp and both she and Dominique O'Dea counted the pollen at that site. Mr Jim Caldwell performed the gas chromatography. Alan Pymont, Bruce Kemp, and Bren Weatherstone assisted with fieldwork. The environmental history of The Micalong was based on accounts of personal and family history by Les Hall, Ruth Franklin, and Lexy and Pat Webb, with information provided by Maria Jamieson (Tumut Environment Centre). Thoughtful comments by Rewi Newnham and three anonymous reviewers significantly improved the text.

Abbreviations. ANU, Australian National University; AMS, accelerator mass spectrometry; LGM, Last Glacial Maximum; NSW, New South Wales; SST, sea surface temperature.

\section{References}

Balliere FF. 1866. Balliere's NSW Gazetteer and Road Guide. FF Balliere: Sydney.

Barrows TT, Stone JO, Fifield LK, et al. 2001. Late Pleistocene glaciation of the Kosciuszko Massif, Snowy Mountains, Australia. Quaternary Research 55: 179-189.

Barrows TT, Stone JO, Fifield LK. 2004. Exposure ages for Pleistocene periglacial deposits in Australia. Quaternary Science Reviews 23: 697-708.

Barrows TT, Alloway B, Reeves J. 2013. The AUSTRALASIANINTIMATE project special volume. Quaternary Science Reviews 74: 1-3.

Black MP, Mooney SD. 2006. Holocene fire history from the Greater Blue Mountains World Heritage Area, New South Wales, Australia: the climate, humans and fire nexus. Regional Environmental Change 6: 41-51.

Bland W. 1831. Journey of Discovery to Port Phillip, New South Wales; by Messrs. W.H. Hovell, and Hamilton Hume: in 1824 and 1825. A. Hill, Printer: Sydney.

Blom WM, Alsop DB. 1988. Carbonate mud sedimentation on a temperate shelf: Bass Basin, southeastern Australia. Sedimentary Geology 60: 269-280.

Bostock HC, Opdyke BN, Gagan MK, et al. 2006. Glacial/interglacial changes in the East Australian current. Climate Dynamics 26: 645659.

Bureau of Meteorology. 2013. Climate Data Online. Available at www.bom.gov.au/climate/data/. Last accessed 19 November 2013.

Calvo E, Pelejero C, De Deckker P, et al. 2007. Antarctic deglacial pattern in a $30 \mathrm{kyr}$ record of sea surface temperature offshore South Australia. Geophysical Research Letters 34: L13707.

Costin AB. 1954. A Study of the Ecosystems of the Monaro Region of New South Wales with Special Reference to Soil Erosion. Government Printer: Sydney.

Costin AB. 1972. Carbon-14 dates from the Snowy Mountains Area, southeastern Australia, and their interpretation. Quaternary Research 2: 579-590.

De Deckker P, Moros M, Perner K, et al. 2012. Influence of the tropics and southern westerlies on glacial interhemispheric asymmetry. Nature Geoscience 5: 266-269.

Dodson JR. 1986. Holocene vegetation and environments near Goulburn, New South Wales. Australian Journal of Botany 34: 231-249.
Dodson JR. 1987. Mire development and environmental change, Barrington Tops, New South Wales, Australia. Quaternary Research 27: 73-81.

Dodson JR. 1998. Timing and response of vegetation change to Milankovitch forcing in temperate Australia and New Zealand. Global and Planetary Change 18: 161-174.

Dodson JR, Greenwood PW, Jones RL. 1986. Holocene forest and wetland vegetation dynamics at Barrington Tops, New South Wales. Journal of Biogeography 13: 561-585.

Dodson JR, Wright RVS. 1989. Humid to arid to subhumid vegetation shift on Pilliga Sandstone, Ulungra Springs, New South Wales. Quaternary Research 32: 182-192.

Dolman G. 1991. Carbonised particle automated counting software. Unpublished software.

Donders TH, Haberle SG, Hope GS, et al. 2007. Pollen evidence for the transition of the Eastern Australian climate system from the post-glacial to the present-day ENSO mode. Quaternary Science Reviews 26: 1621-1637.

Eriksson MG, Olley JM, Kilham DR, et al. 2006. Aggradation and incision since the very late Pleistocene in the Naas River, southeastern Australia. Geomorphology 81: 66-88.

Faegri K, Iverson J. 1964. Textbook of Pollen Analysis. Munksgaard: Copenhagen.

Fitzsimmons KE, Barrows TT. 2010. Holocene hydrologic variability in temperate southeastern Australia: an example from Lake George, New South Wales. The Holocene 20: 585-597.

Flood JM. 1980. The Moth Hunters: Aboriginal Prehistory of the Australian Alps. Australian Institute of Aboriginal Studies: Canberra.

Galloway RW. 1965. Late Quaternary climates in Australia. Journal of Geology 73: 603-618.

Gingele F, De Deckker P, Norman M. 2007. Late Pleistocene and Holocene climate of SE Australia reconstructed from dust and river loads deposited offshore the River Murray mouth. Earth and Planetary Science Letters 255: 257-272.

Gupta SK, Polach H. 1985. Radiocarbon Dating Practices at ANU. Australian National University Press: Canberra.

Grimm EC. 1987. CONISS: A Fortran 77 program for stratigraphically constrained cluster analysis by the method of incremental sum of squares. Computers and Geosciences 13: 13-35.

Grimm EC. 1990. TILIA and TILIA GRAPH: PC spreadsheet and graphics software for pollen data. INQUA - Commission for the Study of the Holocene. Working Groups on Data-Handling Methods Newsletter 4: 5-7.

Heiri O, Lotter AF, Lemcke G. 2001. Loss on ignition as a method for estimating organic and carbonate content in sediments: reproducibility and comparability of results. Journal of Palaeolimnology 25: 101-110.

Hiscock P. 1983. A preliminary archaeological investigation of peat bog areas in the Southern Tablelandsn, New South Wales. A report to the National Parks and Wildlife Service, New South Wales in conjuction with Dr. G Hope and Ms. W. Southern. In Organic Deposits of the Southern Tablelands, Hope G, Southern W (eds) Appendix 4.

Hogg AG, Hua Q, Blackwell PG, et al. 2013. SHCAL13 Southern hemisphere calibration, 0-50,000 years cal BP. Radiocarbon 55: 1889-1903.

Hope G, Kershaw AP, van der Kaars S, et al. 2004. History of vegetation and habitat change in the Austral-Asian region. Quaternary International 118-119: 103-126.

Hope GS. 2006. Histories of wetlands in the Australian Capital Territory and the bog recovery program. In Caring for Namadgi Science and People, McCue K, Lenz S, Freidrich S (eds) Proceedings of the NPA ACT Symposium Canberra May 2006. National Parks Association ACT: Canberra; 129-144.

Hope GS, Nanson R, Flett I. 2009. The Peat-Forming Mires of the Australian Capital Territory. Technical Report 19, Territory and Municipal Services, ACT Government: Canberra.

Hope GS, Nanson R, Jones P. 2012. The Peat-Forming Bogs and Fens of the Snowy Mountains of New South Wales. NSW Parks and Wildlife Service Technical Report.

Hope GS, Southern W. 1983. Organic Deposits of the Southern Tablelands Region, New South Wales. National Parks and Wildlife Service: Sydney. 
Kemp J, Radke LC, Olley J, et al. 2012. Holocene lake salinity changes in the Wimmera, southeastern Australia, provide evidence for millennial-scale climate variability. Quaternary Research 77: 65-76.

Lopes dos Santos RA, Spooner MI, Barrows TT, et al. 2013. Comparison of organic (UK' 37, TEXH 86, LDI) and faunal proxies (foraminiferal assemblages) for reconstruction of late Quaternary sea surface temperature variability from offshore southeastern Australia. Paleoceanography 28: 377-387.

Macphail MK. 1981. Fossil Pomaderris apetala-type pollen in NorthWest Nelson: reflecting extension of wet sclerophyll forests in south-eastern Australia? New Zealand Journal of Botany 19: 17-22.

Macphail MK, Hope GS. 1985. Late Holocene mire development in montane southeastern Australia: a sensitive climatic indicator. Search 15: 344-349.

Martin ARH. 1986. Late glacial and Holocene alpine pollen diagrams from the Kosciusko National Park, New South Wales, Australia. Review of Palaeobotany and Palynology 47: 367-409.

Martin ARH. 1999. Pollen analysis of Digger's Creek Bog, Kosciuszko National Park: vegetation history and tree-line change. Australian Journal of Botany 47: 725-744.

McDougall KL, Walsh NG. 2007. Treeless vegetation of the Australian Alps. Cunninghamia 10: 1-57.

Page K, Carden YR. 1988. Channel adjustment following the crossing of a threshold: Tarcutta Creek, southeastern Australia. Australian Geographical Studies 36: 289-311.

Page K, Nanson G, Price D. 1996. Chronology of Murrumbidgee River palaeochannels on the Riverine Plain, southeastern Australia. Journal of Quaternary Science 11: 311-336.

Reeves JM, Barrows TT, Cohen TJ, et al. 2013. Climate variability over the last 35,000 years recorded in marine and terrestrial archives in the Australian region: an OZ-INTIMATE compilation. Quaternary Science Reviews 74: 21-34.

Robbie A, Martin HA. 2007. The history of the vegetation from the Last Glacial Maximum at Mountain Lagoon, Blue Mountains, New
South Wales. Proceedings of the Linnean Society of New South Wales 128: 57-80.

Singh G, Geissler EA. 1985. Late Cainozoic History of Vegetation, Fire, Lake Levels and Climate, at Lake George, New South Wales, Australia. Philosophical Transactions of the Royal Society B: Biological Sciences 311: 379-447.

Slatyer RO. 1989. Alpine and valley bottom treelines. In The Scientific Significance of the Australian Alps, Good RB (ed.). Australian Alps National Parks Liaison Committee: Canberra; 169184.

Stern H, De Hoedt G, Ernst J. 2000. Objective classification of Australian climates. Australian Meteorological Magazine 49: 8796.

Stuiver M, Reimer PJ, Reimer RW. 2005. CALIB; 5.0. [WWW program and documentation].

Sweller S, Martin HA. 2001. A 40,000 year vegetation history and climatic interpretations of Burraga Swamp, Barrington Tops, New South Wales. Quaternary International 83-85: 233-244.

Wasson RJ, Mazari RK, Starr B, et al. 1998. The recent history of erosion and sedimentation on the Southern Tablelands of southeastern Australia: sediment flux dominated by channel incision. Geomorphology 24: 291-308.

Whinam J, Chilcott N. 2002. Floristic description and environmental relationships of Sphagnum communities in NSW and the $\mathrm{ACT}$ and their conservation management. Cunninghamia 7: 463500.

Williams MAJ. 1978. Late Holocene hillslope mantles and stream aggradation in the Southern Tablelands, N.S.W. Search 9: 96-97.

Williams NJ, Harle KJ, Gale SJ, et al. 2006. The vegetation history of the last glacial-interglacial cycle in eastern New South Wales, Australia. Journal of Quaternary Science 21: 735-750.

Wilkins D, Gouramanis C, De Deckker P, et al. 2013. Holocene lake-level fluctuations in Lakes Keilambete and Gnotuk, southwestern Victoria, Australia. The Holocene 23: 784-795. 